\title{
The Cyclicality of Monetary and Fiscal Policy in South Africa since 1994
}

Stan du Plessis, Ben Smit, and Federico Sturzenegger

CID Working Paper No. 163

May 2008

(C) Copyright 2008 Stan du Plessis, Ben Smit, Federico Sturzenegger and the President and Fellows of Harvard College
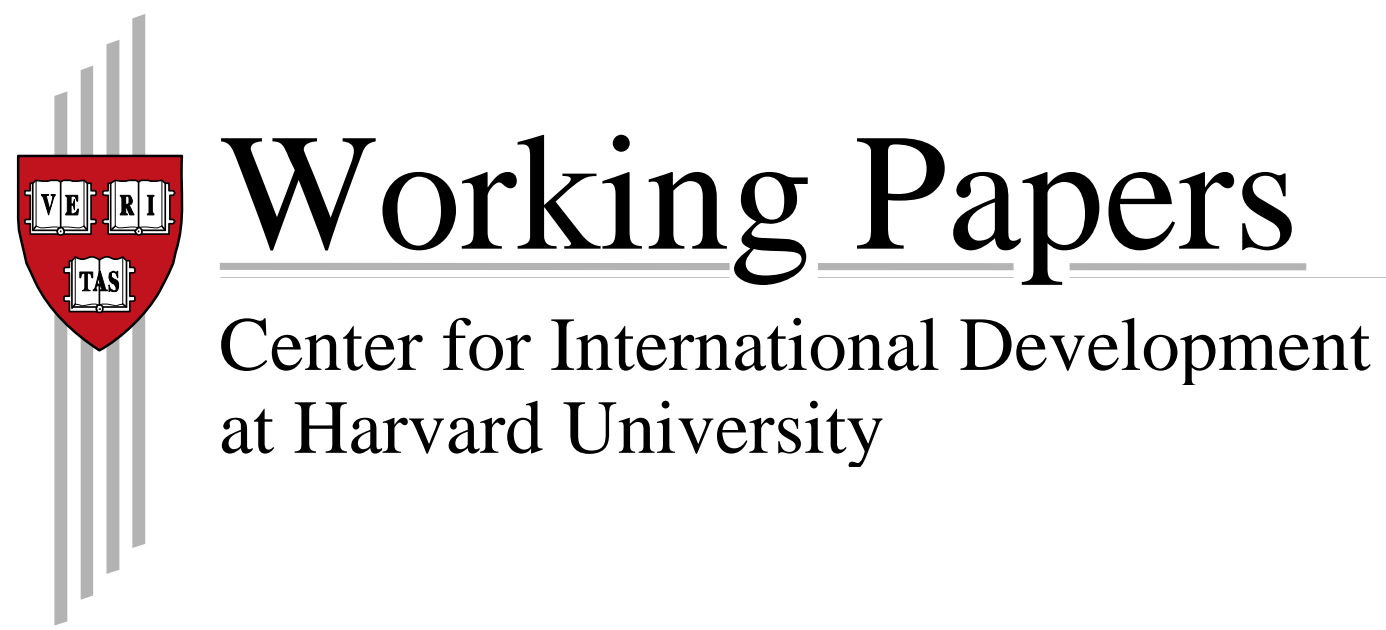


\title{
The Cyclicality of Monetary and Fiscal Policy in South Africa since 1994
}

Stan du Plessis, Ben Smit, and Federico Sturzenegger

May 2008

\begin{abstract}
This paper uses an SVAR approach to discuss the cyclicality of fiscal and monetary policy in South Africa since 1994. There is substantial South African literature on this topic, but much disagreement remains. Though not undisputed, there is growing consensus that monetary policy has contributed to the remarkable stabilization of the South African economy over this period. The evaluation of the role of fiscal policy in stabilization has been less favorable and there is little evidence that a countercyclical fiscal stance was a priority over this period. This paper considers these issues in an empirical framework that addresses some of the shortcomings in the literature. Specifically, it constructs a structural model in contrast with the reduced form models typically used in the South African literature, incorporates the dynamic interaction between monetary and fiscal shocks on the demand side and supply shocks on the other, and avoids controversy over 'neutral' base years and the size of fiscal elasticities. The model confirms the consensus on monetary policy, finding it to have been largely countercyclical since 1994. On fiscal policy, this paper finds evidence of pro-cyclicality, especially in the more recent period, though the policy simulations suggest that the pro-cyclicality of fiscal policy has had little destabilizing impact on real output.
\end{abstract}

Keywords: stabilization policy, monetary policy, inflation targeting, fiscal policy, pro-cyclical policy

JEL Codes: E320, E630

This paper is part of the CID South Africa Growth Initiative. This project is an initiative of the National Treasury of the Republic of South Africa within the government's Accelerated and Shared Growth Initiative (ASGI-SA), which seeks to consolidate the gains of post-transition economic stability and accelerate growth in order to create employment and improve the livelihoods of all South Africans. For more information and the entire series of papers, visit the project's web site at http://www.cid.harvard.edu/southafrica. 


\title{
THE CYCLICALITY OF MONETARY AND FISCAL POLICY IN SOUTH AFRICA SINCE 1994
}

\author{
STAN DU PLESSIS*, BEN SMIT ${ }^{* *}$ FEDERICO STURZENEGGER ${ }^{* * *}$
}

July 2007

\begin{abstract}
A bstract
This paper uses an SVAR approach to discuss the cyclicality of fiscal and monetary policy in South Africa since 1994. There is substantial South African literature on this topic, but much disagreement remains. Though not undisputed, there is growing consensus that monetary policy has contributed to the remarkable stabilisation of the South African economy over this period. The evaluation of the role of fiscal policy in stabilisation has been less favourable and there is little evidence that a countercyclical fiscal stance was a priority over this period. This paper considers these issues in an empirical framework that addresses some of the shortcomings in the literature. Specifically, it constructs a structural model in contrast with the reduced form models typically used in the South African literature, incorporates the dynamic interaction between monetary and fiscal shocks on the demand side and supply shocks on the other, and avoids controversy over 'neutral' base years and the size of fiscal elasticities. The model confirms the consensus on monetary policy, finding it to have been largely countercyclical since 1994. On fiscal policy, this paper finds evidence of pro-cyclicality, especially in the more recent period, though the policy simulations suggest that the pro-cyclicality of fiscal policy has had little destabilising impact on real output.
\end{abstract}

JEL Codes: E320, E630

Key words: Stabilisation policy, monetary policy, inflation targeting, fiscal policy, pro-cyclical

policy

* Department of Economics, University of Stellenbosch

** Department of Economics, University of Stellenbosch

*** Kennedy School of Government, Harvard University and Universidad Torcuato Di Tella

\footnotetext{
1 The authors would like to thank Pablo Gluzman for his invaluable research assistance. This paper is part of the government of South Africa's joint initiative with Harvard University to identify South Africa's binding constraints on growth. The opinions of this paper represent the views of the authors and not those of the Government of South Africa or Harvard University.
} 
"The stakes in choosing the right monetary and fiscal policies are high" Robert Lucas (2003: 3) argued in his presidential address to the American Economic Association. Mistakes at this level cause inflation, distort decisions in labour and capital markets, and might either precipitate or fail to prevent recessions. Lucas proceeded to calculate the potential welfare gain of improving fiscal and monetary policies to attain an 'optimal' stabilisation policy and found that the potential welfare gains from such improvements were orders of magnitude smaller than the potential gains from supply-side policy reforms. Whether this result and the associated policy priorities also hold for South Africa is an empirical question, and this paper contributes towards an answer thereto by estimating (i) the extent to which monetary and fiscal policies have been pro- or anticyclical since 1994 and (ii) the effect of these cyclical characteristics on output volatility in South Africa.

This paper examines the cyclicality of monetary and fiscal policies in an empirical framework that distinguishes between ransitory 'aggregate demand' and permanent 'aggregate supply' shocks, building on the earlier work of Shapiro and Watson (1988), Blanchard and Quah (1989), and Clarida and Gali (1994). Using additional identifying restrictions allows us to disaggregate the demand shock into separate fiscal and monetary policy shocks. These results are described briefly in the second section of the paper, following an introductory section on the relevant literature in South Africa. The third section of the paper uses the identified monetary and fiscal polices to answer the questions about the cyclicality of policy posed above. A counterfactual policy simulation is used to judge the potential gains from more consistent counter-cyclical monetary and fiscal policies in South Africa. 


\section{LITERATURE}

Over the last ten years the South African economy has experienced a remarkable period of economic stability coupled, since 1999, with the longest business cycle expansion in the country's history. Indeed a 'great moderation' - as the improvement in economic stability has been called in the literature on developed economies (for example, Blanchard and Simon, 2001; Stock and Watson, 2003) - has come about in South Africa. The important dimensions of the South African moderation include lower and stable inflation, lower and stable real interest rates, positive and steady GDP growth, and stable fiscal deficits, and debt (for example, Aron and Muellbauer, 2005: 134-138).

Figure 1 summarises this 'great moderation' in the form of a standard loss function ${ }^{2}$ for South Africa since the mid-sixties. It shows a loss function, combining the variability of inflation and real output for three different assumptions of the relative importance of output and inflation variability. Figure 1 shows that the economy was considerably more stable during the first and last decades under consideration, regardless of the relative importance given to output and inflation variability. In other words, the judgement that the South African economy has experienced a 'great moderation' does not depend on the reader's viewpoint with respect to the relative importance of output and inflation stability.

\footnotetext{
${ }^{2} \mathrm{~A}$ loss function combines various dimensions of a problem into a single figure. In this case, output and inflation variability are combined to form a single 'loss' for society at every date.

${ }^{3}$ The loss function was constructed by calculating, for each of the 4 decades shown (1965-1974, 19751984, 1985-1994, 1995-2004), the ratio of the variance to the mean of real GDP growth and year-to-year consumer price inflation. The three loss functions have different weights, with the low inflation aversion using a weight of 0.25 for inflation variability, the medium inflation aversion function having equal weights for inflation and real output growth variability and the high inflation aversion function implying the use of a weight of 0.75 for inflation variability.
} 
Figure 1 about here

It is not just relative to its own history that the South African economy has experienced remarkable stabilisation, but also relative to the experience of other emerging market economies. Figure 2 shows a cross plot (over the period 1996 to 2006) of inflation variability (on the $\mathrm{x}$-axis) against output variability (on the $\mathrm{y}$-axis) for the countries of the Morgan Stanley Capital International (MSCI) Emerging Markets Index ${ }^{4}$ Evidently, the South African economy has benefited from an exceptionally benign environment (in terms of output and inflation stability) compared to most of its peers in the emerging market group.

Figure 2 about here

Many factors are associated with 'great moderations'. While the international environment has been less disruptive in recent years, in the earlier part of this period it subjected the economy to considerable external shocks in the wake of the Mexican, Asian, Russian-Brazilian and Argentinean capital market crises. However, during this period the South African economy has become progressively more open to international capital flows and trade. Trade openness leads to lower volatility through a

\footnotetext{
${ }^{4}$ Figure 2 is a cross plot with the ratio of the standard deviation to the mean of annual consumer price inflation on the x-axis and the ratio of the standard deviation to the mean of annual real GDP growth on the y-axis, the standard deviations and means having been calculated with quarterly IFS data from Q11996 until Q2006.

${ }^{5}$ The extent to which the South African economy has effectively opened up to international trade and
} 
number of channels. Firstly, openness reduces the effectiveness of monetary policy as the prices of more goods become linked to the exchange rate, thus reducing the incentives to pursue inflationary policies (see Rogoff, 1985; Romer, D.H., 1993). Secondly, it allows for a quicker recovery from external shocks (Calvo, Izquierdo and Mejía, 2003; Guidotti, Sturzenegger and Villar, 2004). Finally, Cavallo and Frankel (2004) provide evidence that the possibility of a 'sudden stop' is smaller for countries which are more open to trade.

Another factor associated with the 'great moderation' is the successful political transition during the early nineties, culminating in the first election under universal franchise in April 1994, which has been associated with a marked drop in systemic uncertainty due to social and political factors. Fedderke, de Kadt and Luiz (2001) provide empirical evidence of the decline in political instability since the early nineties. Du Plessis, Smit and Sturzenegger (2007) show how potential output had declined precipitously relative to trend in the two decades prior to 1994 , a process associated with the internal and external opposition to the system of Apartheid and considerable instability connected to the upcoming change in political regime. The process of decline not only stabilised but reverted after 1994 .

Aron and Muellbauer (2005) list further systemic risk factors that have declined since 1994, including the closure of the net open forward position at the South African

competition is a matter of some controversy. Fedderke and Vaze (2001) have argued that despite the decline in average barriers since the early nineties, the effective protection of large domestic sectors, such as the financial sector and mining, have risen over the same period. More recently Edwards and Lawrence (2006) disputed Fedderke and Vaze (2001) with empirical evidence of effective liberalisation at the aggregate and sectoral level in South Africa since the late 1980s. This is consistent with Arora and Bhundia's (2003) earlier interpretation of the sharp rise in South Africa's trade ratio over this period. 
Reserve Bank, and moves toward a more systematic fiscal and monetary policy. It is this claim - that monetary and fiscal policies have contributed to a less volatile economic environment in South Africa since 1994 - that is at stake in this paper. The remainder of this section summarises the literature on the cyclicality of fiscal and monetary policies in South Africa over this period.

\subsection{Fiscal policy}

Though the history of fiscal policy in South Africa since 19946 is one of extraordinary success on important dimensions - such as stabilising the debt to GDP ratio, lowering the interest burden, achieving a considerable transfer of resources from richer to poorer households, and adopting a multi-year and forward-looking framework for budget planning - some of its dimensions were controversial. Part of this controversy - Weeks (1999) is a good example - is about the role of fiscal policy in stimulating growth, with critics arguing for a more expansionary fiscal stance to boost the long-run growth rate of the economy. There is also controversy about the cyclicality of fiscal policy, or the claim that fiscal policy has become pro-cyclical in South Africa, as in many other developing countries (Frankel, Smit and Sturzenegger, 2007: 61).

It is true that there is little evidence of fiscal policy being used intentionally as a counter-cyclical policy tool since 19947. Only three times since 1996 has the Minister of Finance, Trevor Manuel, explicitly mentioned that the planned fiscal stance was

${ }^{6}$ Calitz and Siebrits (2003) and Ajam and Aron (2007) are useful accounts of this history.

7 Calitz and Siebrits (2003: 56) argued that the fiscal authorities in South Africa had not entertained Keynesian policies of active discretionary countercyclical policies since the late seventies. 
adjusted for the economic cycle, though the minister has often referred to the 'expansionary' stance of fiscal policy since 2002. The explicit references are the Medium Term Budget Policy Statement of October 1998 (Manuel, 1998) and the Budget Speech of February 2001 (Manuel, 2001), both of which referred to intentional expansionary fiscal stances, and the reference to a more contractionary stance, in his 2007 budget (Manuel, 2007: 10), as an appropriate part of creating 'a check on emerging imbalances in the economy.

Despite the intentions of fiscal authorities, automatic stabilisers could generate countercyclical policy, which means that the actual cyclicality of fiscal policy is an empirical question to be resolved using various measures. The recent South African literature on the topic has seen the use of four different empirical measures, viz.: (i) using a structural budget balance (Swanepoel and Schoeman, 2003), (ii) the calculation of cyclically adjusted fiscal impulse (Horton, 2005; Ajam and Aron, 2007; Swanepoel, 2007), (iii) an analysis of government expenditure (Du Plessis, 2004), and (iv) using a structural vector-autoregression (SVAR) to identify the fiscal policy (Frankel et al., 2007).

\section{Structural budget balance}

There are different definitions of a 'structural' budget balance. In the South African literature Swanepoel and Schoeman (2003) and Swanepoel (2004) calculate the structural primary budget balance after adjusting the components of government revenue and expenditure for the output gap. This adjustment requires an estimate of the output elasticities of the various components of government expenditure and 
revenue (though in South Africa only the revenue side of the budget has numerically relevant automatic stabilisers). A comparison of the resulting structural budget balance with the unfolding economic cycle indicates the extent to which discretionary fiscal policy has been pro- and counter-cyclical. Swanepoel and Schoeman (2003) and Swanepoel (2004) recently used this technique to judge the cyclicality of fiscal policy in South Africa since the seventies. For the post-1994 period their conclusion was that fiscal policy has often been pro-cyclical since the early nineties, partly due to the weak automatic stabilisers implied by their calculations.

Du Plessis and Boshoff (2007) offer a more recent calculation of the structural budget balance, in the same tradition, but differ from the Swanepoel studies in three ways: (i) by substituting quarterly data for the annual data used by Swanepoel, (ii) by reestimating the output elasticities of various components of government revenue, and (iii) by substituting the alternative measure of the business cycle proposed by $\mathrm{Du}$ Plessis, Smit and Sturzenegger (2007) for the Hodrick-Prescott-based measure used by Swanepoel.

The results of Du Plessis and Boshoff (2007) differ in important respects from the earlier results by Swanepoel and Schoeman (2003) and Swanepoel (2004). Firstly, the output elasticities of government revenue as estimated by Du Plessis and Boshoff (2007) are more than twice as high as the estimates by Swanepoel and Schoeman (2003) and closer to similar estimates for developed countries. This comparison of the output elasticities of government revenue is repeated in table 1 below which shows the estimates of Du Plessis and Boshoff (2007), those of Swanepoel and Schoeman (2003) 
and comparable estimates for the OECD (Girouard and André, 2005).

Table 1 about here

The actual and structural budgets for South Africa as estimated by Du Plessis and Boshoff (2007) are shown in Figure 3. During the downswing from 1989 to 1993 and the subsequent upswing, the structural budget balance moved counter-cyclically. This was followed by a pro-cyclical decline of the structural budget balance during the downswing of 1997 to 1999 and an ambiguous trend during the present expansion. This evidence does not support any strong opinion about the cyclicality of discretionary fiscal policy over this period, and this result is the second notable contrast between $\mathrm{Du}$ Plessis and Boshoff (2007) and Swanepoel and Schoeman (2003).

Figure 3 about here

Thirdly, while Swanepoel's (2004) results suggest that automatic stabilisers have been eroded in South Africa, Du Plessis and Boshoff (2007) show the opposite, i.e. that automatic stabilisers operated as expected during the downswing of 1997/99 as well as during the present expansion. This claim is supported by Figure 3 which shows a widening gap between the actual and structural budget balance during the 1997 to 1998 downswing and a closing of that gap as actual output catches up with potential output during the present expansion.

An alternative computation is undertaken by Ortiz, Talvi and Sturzenegger (2007). 
They provide a simple exercise which is to replicate the Chilean structural fiscal rule. The Chileans aim for a structural surplus of $1 \%$ of GDP (recently reduced to $0.5 \%$ ), where the structural surplus is defined by using permanent, i.e. cyclically adjusted revenues. To estimate these usable' revenues Ortiz et al. (2007) first compute the Lagrange multiplier of the Hodrick-Prescott filter for current revenues in Chile, which aims at assessing how much the Chilean authorities smooth their income. The Lagrange multiplier that delivers a surplus/deficit matching the structural deficit reported by the authorities is the one that provides a statistical equivalent to their complex rules for determining sustainable income. ${ }^{8}$ They then apply this filter to revenues from other countries to compute their 'structural balances'. The results for South Africa are presented in Figure 4, which shows how South African authorities reduced the structural balance during the 1990s. In recent years, however, while the observed deficit has decreased and finally turned into a surplus, the structural deficit has increased quite dramatically, signalling that the current surplus is the result of what could be considered extraordinary revenues.

Figure 4 about here

\section{The fiscal impulse}

An alternative method for distinguishing between the automatic and discretionary components of fiscal policy is the calculation of a fiscal impulse, where this is defined

\footnotetext{
8 The Chilean rule is determined, in part, by a committee of experts that suggests which portion of the resources should be considered sustainable and which should not, particularly those arising from royalties on copper production. Obviously, this rule is not replicable for other countries, thus the methodology for finding a 'statistical equivalent' to it.
} 
as the change in the stance of fiscal policy due to discretionary decisions on taxation and expenditure (Chand, 1977; Schinasi and Lutz, 1991). This method also requires adjustments to government revenue and expenditure due to the effects of the economic cycle (and sometimes inflation), to identify the fiscal impulse. It has been attempted in three recent papers in the South African literature, namely, Horton (2005), Ajam and Aron (2007), and Swanepoel (2007).

The papers by Horton (2005) and Ajam and Aron (2007) pursue the same version of the fiscal impulse and their method is as follows: Firstly, they define government revenue and expenditure in a base period as 'neutral', with Horton selecting the fiscal year 1998/99, and Ajam and Aron selecting the fiscal year 2000/01 for this purpose9. Secondly, both sets of authors assume that neutral non-interest government expenditure evolves with potential GDP10, while neutral government revenue evolves with actual GDP. Thirdly, given these assumptions, a neutral primary balance can be calculated for each period, and the fiscal stance is defined as the difference between this neutral primary balance and actual primary balance in every period ${ }^{11}$. The fiscal impulse, in turn, is defined as the change in the fiscal stance between successive years. Using this technique Horton (2005) and Ajam and Aron (2007) find evidence of pro-cyclical fiscal policy, especially in the first few years following the elections in 1994 and during the present expansion.

As an alternative to calculating the fiscal stance and fiscal impulse relative to a base

\footnotetext{
${ }^{9}$ The economy is supposed to be operating at or near potential GDP in the base year.

${ }^{10}$ Identified by applying a Hodrick-Prescott filter to real GDP in both papers.

11 A positive fiscal stance, so defined, is accommodating, while a negative fiscal stance is contractionary.
} 
period as described above, Swanepoel (2007) calculated the fiscal impulse using a technique derived from Blanchard (1990). Accordingly, government revenue is adjusted for changes to the unemployment rate over time, and the fiscal impulse is defined as the difference between unemployment adjusted budget balances for successive years. Swanepoel (2007) finds that the Blanchard fiscal impulse is closely related to the changes in the structural budget balance as reported in Swanepoel (2004), and hence confirms his claim that fiscal policy has been mainly pro-cyclical since 1994.

But these results have been challenged by Du Plessis and Boshoff (2007) who argued that (i) Horton (2005) and Ajam and Aron (2007) chose inappropriate base periods, as the South African economy was not operating close to potential during the downswing of 1998/99 or during the modest initial phase of the present expansion in 2000/01, and (ii) the use of the Hodrick-Prescott filter on annual data provides a poor description of the South African business cycle over this period. Du Plessis and Boshoff (2007) used the alternative business cycle measure ${ }^{12}$ proposed in Du Plessis et al. (2007) to define 2005Q2 as the neutral base period when actual output was close to potential output. The same business cycle measure was used to calculate the fiscal stance and fiscal impulse.

Figure 5 about here

The alternative base year and alternative cycle led Du Plessis and Boshoff (2007) to a

12 This measure of the business cycle is identified using a structural VAR with long-run restriction in the tradition of Blanchard and Quah (1989). 
different conclusion on the cyclicality of fiscal policy since the early nineties; the preponderance of points in the top-left quadrant of Figure 5 suggests that the stance of fiscal policy has often been counter-cyclical in South Africa over this period. This is true of two-thirds of the quarters between 1992Q1 and 2006Q3.

However, two observations lead one to interpret the evidence of counter-cyclical fiscal policy cautiously. Firstly, the fiscal stance deteriorated sharply between 1997 and 1999, which was also the period when the output gap reached its largest negative value ${ }^{13}$. Indeed, if the fiscal impulse (the change in the fiscal stance) is substituted for the fiscal stance in Figure 3 above, then the evidence of counter-cyclical fiscal policy largely disappears. Secondly, if fiscal policy operated successfully as a counter-cyclical tool, we would see a pattern matching large output gaps with a large fiscal stance. However, there is no sign of such a pattern, suggesting that, even when counter-cyclical, the contribution of fiscal policy to output stabilisation must have been modest.

\section{The cyclicality of govemment expenditure}

Du Plessis (2004) followed Fatás and Mihov (2003: 1422) in using the ratio of government expenditure (without transfer payments) to GDP as a proxy for discretionary fiscal policy. But where Fatás and Mihov (2003) used a regression model to identify the cyclicality of this measure of fiscal policy, Du Plessis (2004) used a business cycle dating algorithm to identify periods of relatively expansionary and relatively contractionary fiscal policy to compare the phases of the South African business cycle.

${ }^{13}$ Horton (2005) also observed this counter-cyclical fiscal contraction over the same period. 
While the ratio of government expenditure (without transfer payments) declined during the downswing of $1998 / 99$, yielding a pro-cyclical fiscal policy, it has continued to decline modestly during the present expansion, yielding a modest counter-cyclical fiscal policy. Though the expansion of government expenditure has so far been prevented from turning pro-cyclical, the considerable increase of transfer payments during the present expansion more than outweighs the small counter-cyclical reduction of government expenditure (Du Plessis and Boshoff, 2007).

In summary, while various authors have identified pro-cyclical fiscal policy in South Africa since 1994, the preceding paragraphs have shown that these results are often open to challenge. This ambiguity provides an important rationale for the SVAR investigation proposed here.

\subsection{Monetary policy}

Since 1994 monetary policy in South Africa has also seen far reaching changes ${ }^{14}$. Since the late 1980s the nominal anchor has evolved from guidelines for growth in monetary aggregates, to 'informal' inflation targeting in the late 1990s and finally comprehensive inflation targeting since February 2000. While the successes, in terms of credibility for the monetary authorities have been considerable (Aron and Muellbauer, 2006), Frankel et al. (2007: 59) highlighted the risk that supply shocks pose to a narrowly defined inflation targeting regime. A 'strict' inflation targeting central bank could, for example, tighten monetary policy in response to an adverse supply shock, yielding pro-cyclical

14 Aron and Muellbauer (2006) provide an thorough summary of these developments. 
monetary policy. The extent to which the South African Reserve Bank (SARB) avoided the risk is an empirical question and a few local authors have investigated various aspects of the question in recent years.

\section{Monetary policy and the phases of the business cycle}

In a recent paper Du Plessis and Smit (2007) used a method proposed by Christina and David Romer (1994) to measure the cyclicality of monetary policy following turning points in the business cycle. While Romer and Romer (1994) found clear evidence that real (and nominal) interest rates declined (rose) cumulatively in the eight quarters following a peak (trough) in economic activity in the USA during the post-War era, Du Plessis and Smit (2007) did not find similar evidence for South Africa since the early 1980s. Indeed, the cumulative change in the real and nominal interest rates was usually perverse. However, a major shortcoming of this methodology is that it neglects the long and variable lags in the monetary policy transmission mechanism.

In a similar spirit, Swanepoel (2004) compared changes in the real short-term interest with the contemporaneous output gap. On this evidence the stance of monetary policy was often pro-cyclical from 1993/4 to 2002/3. However, the same concerns with regards to the lags of the transmission mechanism could be raised here.

\section{Lags in monetary policy transmission and the business cycle}

Du Plessis (2006) attempts to make explicit allowance for the lags in monetary policy transmission when judging the cyclicality of monetary policy. He uses a business cycle dating technique to identify periods of relatively expansionary and contractionary 
monetary policy and compares these 'phases' of the monetary policy cycle with the South African business cycle. This comparison, taking into account a four to six quarter lag for the transmission mechanism, yields a striking result; prior to 1990 there was essentially no relationship between the business cycle and the monetary policy cycle, but after 1990 a clear forward-looking counter-cyclical relationship emerges.

To summarise, there is evidence of pro-cyclical monetary policy in South Africa since the early nineties. However, much of the evidence ignores lags in the monetary policy transmission mechanism.

\section{IDENTIFYING FISCAL AND MONETARY POLICY SHOCKS: AN SVAR ANALYSIS}

The literature summarised in the previous section does not give a clear message on the cyclicality of monetary and fiscal policy in South Africa. Many of the results were heavily dependent on contestable assumptions about base years, elasticities, measures of the business cycle, a narrow view of the dynamics of macroeconomic relationships, and a single-variable approach to multi-variable problems. They are attempts at model-free policy analysis lacking benchmarks against which to judge the observed policies. This section proposes an empirical framework that addresses some of these shortcomings. Specifically, it constructs a structural model in contrast with the typically reduced form used in the South African literature, provides a multivariate approach that incorporates the dynamic interaction between monetary and fiscal shocks on the demand side and supply shocks on the other, and avoids assumptions about 'neutral' base years and the 
size of elasticities.

The model proposed here is a structural vector autoregression (SVAR) with long-run identifying restrictions in the tradition of Blanchard and Quah (1989). While they used long-run restrictions in a bivariate model to identify aggregate supply and demand shocks, we followed the literature of Galí (1992) and Clarida and Galí (1994) who further disaggregate demand shock. Specifically, we used the three-variable model described in Du Plessis et al. (2007), which uses the information contained in the output, government consumption to GDP, and the real interest rate series, to identify aggregate supply and demand shocks and to subdivide the aggregate demand shocks into identified monetary and fiscal policy shocks.

A number of identifying restrictions are required to map the reduced form VAR estimated with time series data to the structural VAR which is posited as the datagenerating mechanism. These identifying restrictions yield a time series of structural shocks for each of the three variables in the model and for the estimated parameters of the dynamic interactions. The estimated parameters describe how the three structural shocks cumulatively and jointly generate the three variables.

The identification problem in this model requires three additional restrictions, which in the SVAR tradition are specified from theoretical priors. Blanchard and Quah (1989) suggested that long-run neutrality conditions could be used to solve the identification problem and their solution is adopted here too. The first two of these neutrality conditions separate the aggregate supply shock from the two aggregate demand shocks, 
i.e. the restrictions that the fiscal and monetary policy shocks have no long-run impact on real output. The third theoretical restriction states that there are no long-run effects on fiscal policy of the stance on monetary policy. This restriction means that the real interest rate (the proxy for monetary policy) does not have a long-run effects on the ratio of government expenditure to GDP the proxy for fiscal policy), a condition which requires the assumption that the preferences for public goods are independent of the interest cost.

The model was estimated with seasonally adjusted quarterly time series data starting in the second quarter of 1960 and ending in the fourth quarter of 2006. Table 2 shows the variables used in the model. The reduced form VAR was estimated with a lag length of four. To check robustness, the estimation and identification were implemented on the entire sample, starting in the second quarter of 1960 and on a sub-sample, starting in the fourth quarter of 1983.

Table 2 about here

Du Plessis et al. (2007) reported three types of evidence supporting this model: impulse response functions and variance decomposition that were consistent with theoretical priors, and a historical decomposition of aggregate supply and demand shocks that was consistent with independent information about shocks to potential output and to the business cycle.

The historical decomposition referred to above is a technique that uses the dynamic 
interactions and the series of structural shocks to create three different in-sample forecasts for real GDP, dependant on the model and on inputting each structural shock separately. In this manner the model delivers a profile for output when only supply shocks are present, when only monetary shocks are present, or when only fiscal shocks are present. The first in-sample forecast shows how real GDP would have evolved, if this model had been used with only the identified aggregate supply shocks as disturbances (the monetary and fiscal policy shocks having been set to zero). The second in-sample forecast sets the identified aggregate supply and fiscal shocks to zero and uses the model to trace the predicted in-sample evolution of real GDP if the monetary policy shocks were the only identified disturbances to the system. The third in-sample forecast based on the identified fiscal policy shocks was constructed analogously.

\section{MODEL-BASED EVIDENCE ON THE CYCLICALITY OF MONETARY AND FISCAL POLICY}

The SVAR model used here provides three types of evidence on the cyclicality of fiscal and monetary policy. Firstly, impulse response functions show the dynamic responses of the three variables to identified aggregate supply and demand shocks. Secondly, the historical decomposition reveals the time pattern of the monetary and fiscal policy shocks, which could be compared with the historical pattern of supply shocks and with real GDP. Finally, the model could be used to simulate the outcome of alternatives to the observed policy shocks to create a counterfactual with which to compare the observed history. This section explores the evidence from the impulse response functions and the historical decomposition, while the counterfactual analysis is reported 
in section four.

\subsection{Innovation acoounting}

Figures 6 and 7 show the impulse response functions for government consumptions (Figure 6) and the real interest rate (Figure 7) to the three identified shocks, given the model. Impulse response functions are reported for both the longer sample (1960+) and the shorter sample (1983+) to lower the risk of the results being sample specific.

Figure 6 about here

The impulse response graphs in the first row of figure 6 shows that the government consumption to GDP declines in response to a positive supply shock, though this effect disappears over time (more rapidly in the case of the shorter sample). This is a counter-cyclical fiscal response to supply shocks, as it implies that government expenditures lag output expansion temporarily, in response to a positive aggregate supply shock.

While the first row of Figure 6 shows a counter-cyclical fiscal response to supply shocks, the second row shows a mildly pro-cyclical response by government expenditure to a monetary policy shock. A positive shock to the real interest rate (a contractionary demand shock) leads to a mild and short-lived rise in the ratio of government to real GDP, i.e. fiscal policy somewhat counteracts the impact of a monetary policy shock on real GDP. However, the counteractive fiscal effect does not 
remove the intuitive contractionary effect of the monetary policy shock on real GDP, as is shown in Figure 7. Real GDP declines temporarily in response to a contractionary monetary policy shock.

Figure 7 about here

Turning to monetary policy, the first row of Figure 8 shows a temporary rise for the real interest rate in response to a positive aggregate supply shock. This is evidence of a counter-cyclical response by monetary policy in the face of supply shocks, and is important given the concern that monetary policy might respond pro-cyclically under an inflation targeting regime. However, the impulse response functions show the average effect over the entire sample and are not limited to the inflation targeting period since early 2000 .

The second row of Figure 8 shows a temporary decline for the real interest rate in response to an expansionary fiscal policy shock. Such a monetary policy response would amplify the positive impact of expansionary fiscal policy shock.

Figure 8 about here

\subsection{Historical decomposition}

A historical decomposition allows us to assign portions of the historical variation in real GDP to the three identified shocks. The shares of the variation in real GDP attributable to the two policy shocks and their time pattern are of specific interest. 
Figure 9 shows the response of real GDP to fiscal policy shocks for the models estimated over the longer and shorter samples, against a background showing business cycle expansions as shaded areas ${ }^{15}$. There is little evidence of counter-cyclical impact on real GDP for fiscal policy over the sample period. For example, since 1994 fiscal policy moved counter-cyclically during the expansion of 1993 to 1996 but pro-cyclically during the subsequent contraction of 1998 to 1999 and also pro-cyclically during the present expansion.

Figure 9 about here

Figure 10 shows the response of real GDP to monetary policy shocks for the models estimated over the longer and shorter samples, against a background showing business cycle expansions as shaded areas. The scales are identical in Figures 9 and 10 for ease of comparison.

Figure 10 about here

Figure 10 shows that since the early nineties, monetary policy has often had an impact on real GDP, which has been contractionary during downswings and expansionary during upswings. The downswing of 1998 to 1999 is a case in point, as well as the initial and final phases of the current expansion.

15 The phases of the business cycle follow the official turning points for the South African business cycle published by the SARB. 
However, looking at the cyclicality of these policies by comparing the contribution of each shock with the evolution of GDP, is not entirely conclusive, because to the extent that a monetary and fiscal policy tightening leads to a temporary decline in aggregate demand, we expect precisely a temporary decline in real GDP which would be correlated with the business cycle. It follows that GDP fluctuations due to aggregate demand shocks, which are bunched at the business cycle frequencies, will necessarily be correlated with a combination of the identified fiscal and monetary policy shocks.

In order to explore this issue further, we would need to contrast the fiscal and monetary impulses vis-à-vis the other shocks (not the evolution of GDP that is influenced by its own effect), and in particular vis-à-vis supply shocks. Fiscal and monetary policy shocks that exacerbate supply shocks would raise the concern that policy aggravates economic fluctuations. To examine this possibility the following table shows the correlation between the aggregate demand shocks and the supply shocks. Correlations are reported for various samples starting in 1984Q4, reflecting the period of modern market-based monetary policy in South Africa.

Table 3 about here

Over the sample from 1984 to 2006 the cumulative effects on GDP of both fiscal and monetary policy shocks are positively correlated with the cumulative effects of the supply shock. Where fiscal policy is concerned, this correlation is very small in the longer sample model. For both models the correlations are larger in the sub-sample 
from 1994 to 2006. If we split the period since 1994 into two further sub-samples, 1994Q1 to 2002Q1 and 2002Q1 to 2006Q4, another interesting result emerges, i.e. the positive correlation between the output effect of fiscal policy and the cumulative supply shock is almost entirely due to the post-2002 sub-sample. This result holds for both the shorter and longer sample models.

The cumulative effect of the monetary policy shock is positively correlated with the cumulative output effect of the supply shock from 1984 to 2006, but this pro-cyclicality of monetary policy is mainly a feature of the sub-sample 1984 to 1994, for both of the models reported in Table 3. Since 1994 both models show a negative (i.e. countercyclical) correlation. This result is consistent with the evidence of Du Plessis (2006: 772) showing largely pro-cyclical monetary policy from the late 1970 s until the late 1980s, followed by largely counter-cyclical monetary policy since the early 1990s.

The models estimated over the longer and shorter samples yield different patterns of correlation since 1994. Both models find a large positive pro-cyclical correlation between the cumulative monetary policy shock and the cumulative supply shock for the 2004Q4 to 2006Q4 sub-sample. However, the two models differ over the 1994Q1 to 2002Q4 correlation, with the longer sample model yielding a counter-cyclical correlation up to 2002Q1 and an acyclical pattern between 2002Q1 and 2004Q4. In contrast, the shorter sample model yielded a pro-cyclical correlation up to 2002Q1 and a counter-cyclical correlation between 2002Q1 and 2004Q4. These correlations suggest that monetary policy has mainly acted counter-cyclically over the post-1994 period, despite pro-cyclical monetary policy shocks since 2004. 


\section{ALTERNATIVE POLICY RULES AND THE CYCLICALITY OF MONETARY AND FISCAL POLICIES}

The results reported above suggest directions of influence for the potentially stabilising role of monetary and fiscal polices in South Africa but do not yet quantify the magnitude of these effects in comparison with a relevant alternative. However, a model-based study such as this one, lends itself to asking counterfactual questions. Indeed, Fackler and McMillan (1998) show how to use an SVAR to generate a counterfactual for a well defined policy alternative.

One alternative is to assume no further innovations to fiscal and monetary rules since 1994 and set the identified shocks to these policies to zero. This means that these policies would have followed their inertial evolution. Would this deliver a more stable output profile? We examined these counterfactuals by first calculating the standard deviation of real output predicted by the SVAR model over the sample 1994Q1 to 2006Q4 with the three structural shocks. This is called the 'baseline' scenario in Table 4. The baseline is compared with two alternatives. In the first alternative, the identified monetary policy shocks are eliminated to show whether eliminating the observed monetary policy would have stabilised real output in an economy represented by this model. The second alternative repeats this exercise by eliminating the identified fiscal policy shocks over the same period. Both alternatives are calculated with the models estimated over the shorter (starting in 1983) and longer (starting in 1960) samples. 
Table 4 about here

By focusing on the standard deviation of the rate of growth of GDP, the model shows that the identified fiscal shocks had a small destabilising impact on real output in this model, notably for the post-1994 sample. The result holds for all samples and estimations and confirms our result that pro-cyclical fiscal policy appears to have added to output instability. The magnitude of the effect is modest though. Notice that the exercise is to shut off the fiscal shocks since 1994, but this does not preclude fiscal policy responses to supply and monetary policy shocks. As a result, the path for fiscal policy is only slightly more stable than the original (the standard deviation of the changes drops for the period 1994 through 2006 from 0.49 to 0.42 in the short sample, and from 0.45 to 0.38 in the longer sample).

In contrast with the evidence of mildly pro-cyclical fiscal policy shocks, the counterfactual analysis suggests that the identified monetary policy shocks had either lowered the variability of real output over the entire sample (as estimated by the longer period model) or had a neutral impact (as estimated by the shorter period model). This result confirms an earlier counterfactual exercise by Du Plessis and Smit (2003) who used a method developed by Cecchetti, Flores-Lagunes and Krause (2001) to identify the contribution of a more systematic monetary policy to the improved stability of the South African economy post-1994 (with a sample extending to 2002Q4). They found that $55 \%$ of the improved stability in terms of output and inflation variability, could be attributed to a more systematic monetary policy over this period, an estimate which compared favourably with the experience of the developed countries studied by 
Cecchetti, Flores-Lagunes and Krause (2001).

\section{CONCLUSION}

The South African economy has experienced a period of remarkable stabilisation since the early 1990s and this observed stabilisation provides the context for the present investigation into the cyclicality of monetary and fiscal policy in South Africa. The goal was to identify the relevant policy shocks using a model-based technique and then to judge the cyclicality of the policies so identified. A final goal was to estimate an order of magnitude of the contribution made by macroeconomic policy to the stabilisation of the South African economy.

Though there is substantial South African literature on the cyclicality of monetary and fiscal policies, there is little agreement over the results. This paper builds on the literature by considering a model that avoids some of the previous shortcomings, especially the failure to incorporate dynamic and multi-variable effects. Despite this, the results remain somewhat ambiguous: the proxy for the fiscal policy shock shows evidence of pro-cyclicality in the period since 1994, but closer scrutiny of the evidence suggests that the observed pro-cyclicality is all due to the period since 2002 . This caveat does not cancel the evidence of emerging pro-cyclical fiscal policy, but it does suggest caution in interpreting a correlation based on the impact of a policy for what has become a highly exceptional business cycle phase for the South African economy. Further, the model proposed here does not predict that the pro-cyclicality of fiscal policy (such as it was) has had a quantitatively large destabilising impact on real output 
since 1994.

A similar message emerges for monetary policy. Again, there is evidence of procyclicality since 1994, but it is driven by an even more recent period, the end of sample period 2004 to 2006. Earlier sub-samples show evidence of counter-cyclical monetary policy, and the counterfactual analysis suggests that monetary policy has either had no destabilising impact on real output or has stabilised output over the period since 1994. 
Table 1 E stimated output elasticities for components of government revenue

\begin{tabular}{lc}
\hline Revenue component & Elasticity estimate \\
\hline \multicolumn{2}{c}{ D u Plessis and Boshoff (2007) } \\
Total income tax on persons, individuals, & 1.05 \\
corporations and other enterprises & \\
Total taxes on income, profits and capital gains & 0.82 \\
Total taxes on payroll and workforce & 1.19 \\
Transfer duties & 1.27 \\
Total other taxes on property & 1.37 \\
Total taxes on property & 1.35 \\
Value-added tax (total) & 1.14 \\
Value-added tax (domestic) & 1.06 \\
Value-added tax (customs) & 1.40 \\
Fuel levy & 0.67 \\
Other excise duties & 0.85 \\
Total domestic taxes on goods and services & 1.02 \\
Total taxes on international trade and transactions & 0.36 \\
Other taxes & 1.05 \\
Total tax revenue & 1.06 \\
& \\
Direct taxes & Swanepoel and Schoeman (2003) \\
Indirect taxes & \\
Total revenue and grants & 0.42 \\
Corporate tax & 0.19 \\
Personal tax &
\end{tabular}

Source: Du Plessis and Boshoff (2007), Swanepoel and Schoeman (2003), and (Girouard and André, 2005)).

a "Consisting of taxes on net income and profits, donations tax, estate duty and taxes on payroll and workforce" (Swanepoel and Schoeman, 2003: 820) 
Table $2 \quad$ D ata

\begin{tabular}{lll}
\hline Variable & Calculation & Source \\
\hline$\Delta \mathrm{y}_{\mathrm{t}}$ & First difference of the log of real GDP & SARB, RB6006D \\
$\mathrm{g}_{\mathrm{t}}$ & Ratio of government consumption to GDP & SARB, RB6008D, \\
& (does not include interest payments) & RB6006D \\
$\mathrm{r}_{\mathrm{t}}$ & Real interest rate calculated, using monthly & SARB, Discount rate and \\
& data and a within-quarter formula ${ }^{16}$ & CPI index, RB 7032N \\
\hline
\end{tabular}

Table 3 Correlations between acaumulated demand shocks and the accumulated supply shock

\begin{tabular}{|c|c|c|c|c|}
\hline \multirow[t]{4}{*}{ Period } & \multicolumn{4}{|c|}{ Correlation } \\
\hline & \multicolumn{2}{|c|}{ Longer sample } & \multicolumn{2}{|c|}{ Shorter sample } \\
\hline & Fiscal shock vs & Monetary shock vs & Fiscal shock vs & Monetary shock vs \\
\hline & Supply shock & Supply shock & Supply shock & Supply shock \\
\hline 1984Q4-2006Q4 & 0.0333 & 0.2099 & 0.3524 & 0.5780 \\
\hline 1984Q4-1994Q1 & -0.5116 & 0.2697 & -0.7422 & 0.7996 \\
\hline 1994Q1 -2006Q4 & 0.0738 & -0.3034 & 0.7094 & -0.2218 \\
\hline 1994Q1 -2002Q1 & -0.8978 & -0.4553 & -0.5871 & 0.3861 \\
\hline 2002Q1 -2006Q4 & 0.8715 & 0.3605 & 0.9840 & -0.4927 \\
\hline 2002Q1 -2004Q4 & 0.3860 & -0.0706 & 0.9899 & -0.8725 \\
\hline 2004Q4-2006Q4 & 0.8109 & 0.8619 & 0.9207 & 0.9216 \\
\hline
\end{tabular}

${ }^{16}$ For each quarter the real interest rate was calculated using monthly data and the following formula where $\mathrm{m}_{\mathrm{t}}$ means the quarter's middle month:

$$
\operatorname{Avg}\left(i_{m t-1}, i_{m t}, i_{m t+1}\right)-\left\{\left[\ln \left(\frac{C P I_{m t}+C P I_{m t+1}}{2}\right)-\ln \left(\frac{C P I_{m t}+C P I_{m t-1}}{2}\right)\right]^{12}-1\right\}
$$


Table $4 \quad V$ ariability of real output under different policy scenarios

\begin{tabular}{lccc}
\hline & $\begin{array}{c}\text { Standard deviation } \\
\text { of actual GDP }\end{array}$ & $\begin{array}{c}\text { Without monetary } \\
\text { shocks }\end{array}$ & $\begin{array}{c}\text { Without fiscal } \\
\text { shocks }\end{array}$ \\
\hline Shorter sample model & $0.69 \%$ & $0.68 \%$ & $0.66 \%$ \\
1984q4-2006q3 & $0.45 \%$ & $0.44 \%$ & $0.38 \%$ \\
1994q1-2006q3 & & & \\
Longer sample model & $1.12 \%$ & $1.13 \%$ & $1.11 \%$ \\
1961q2-2006q3 & $0.49 \%$ & $0.56 \%$ & $0.42 \%$ \\
1994q1-2006q3 & & & \\
\hline
\end{tabular}


Figure 1 The 'great moderation' of the South A frican economy

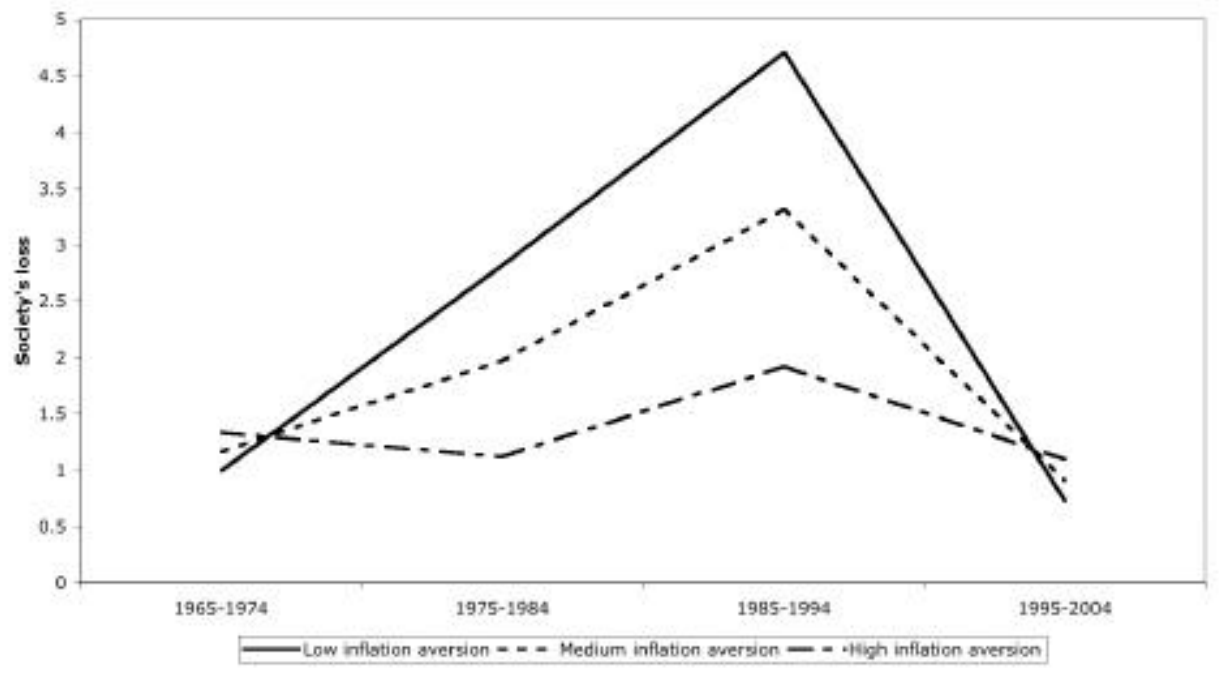

Source: Own calculation from SARB quarterly bulletin data

Figure 2 The stability of the South A frican economy in an international oontext (1996-2006)

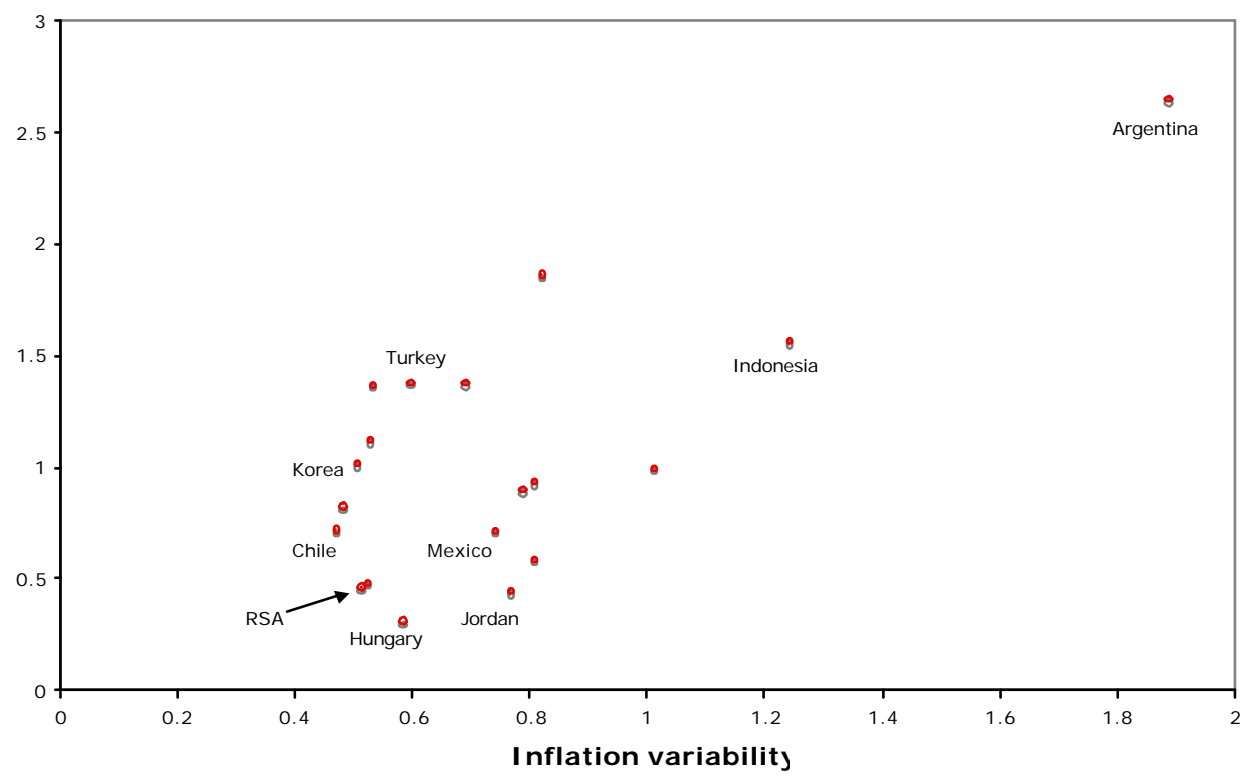

Source: Data from the IFS data base 
Figure 30 bserved and structural budget balanoes for South A frica

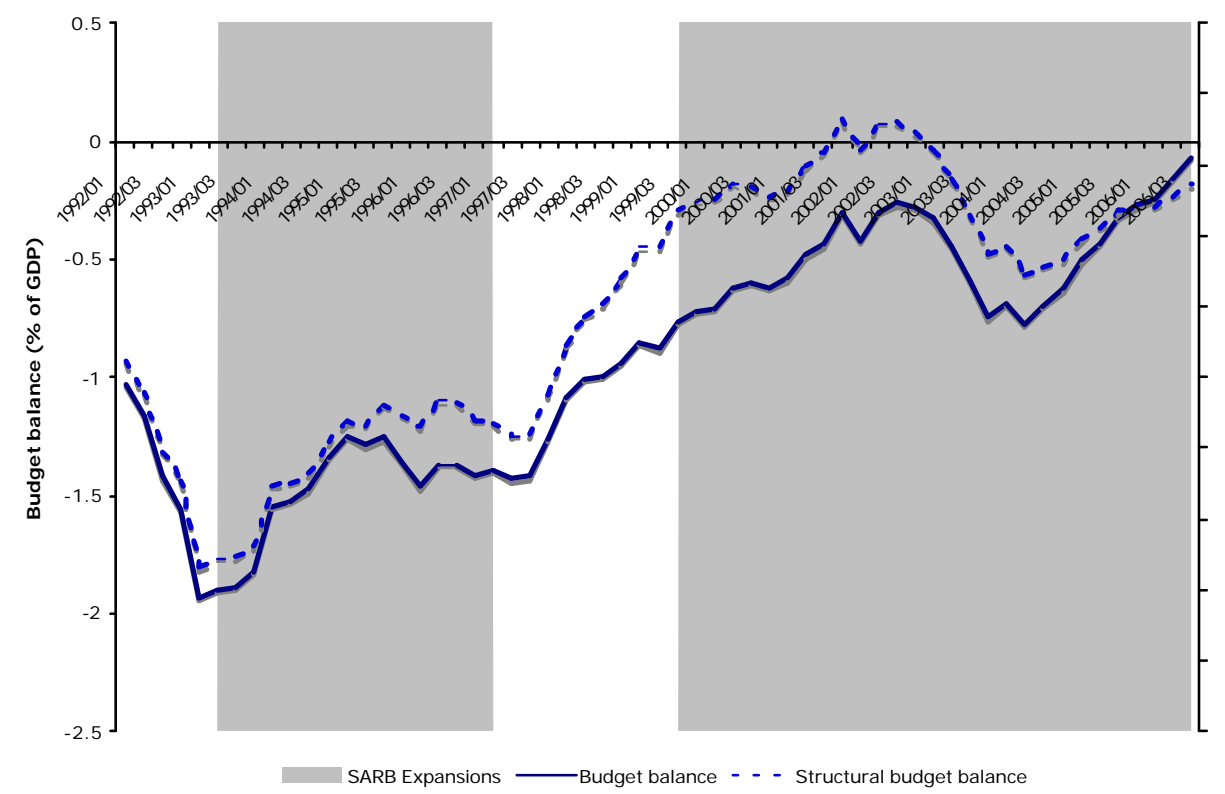

Source: Du Plessis and Boshoff (2007, figure 8)

Figure $4 \quad$ Observed and structural budget balanoes for South A frica using the C hilean method

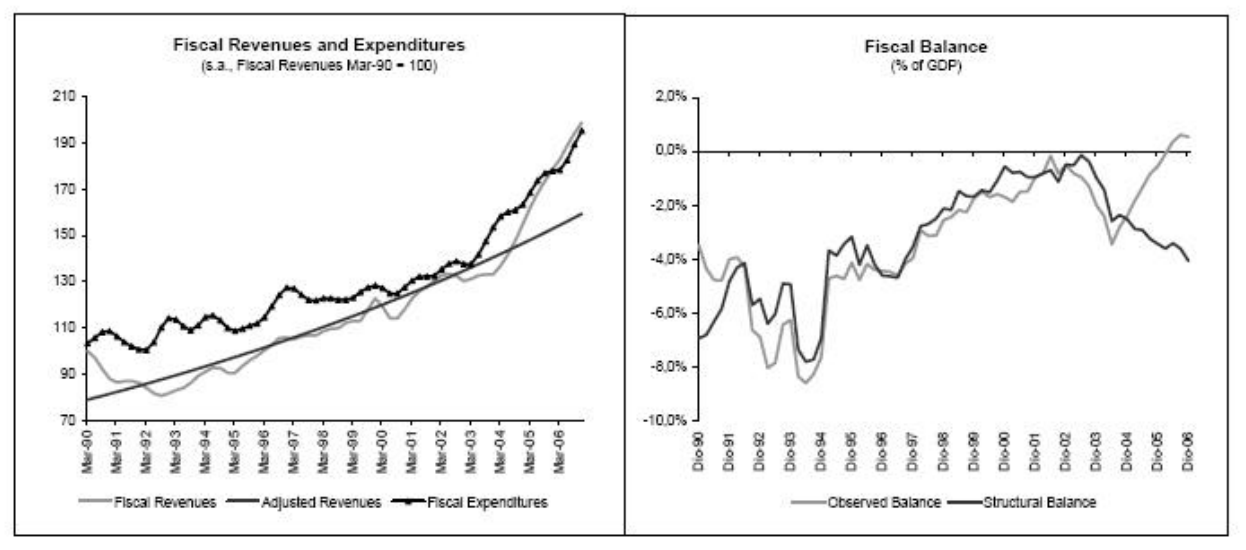


Figure 5 The fiscal stanœ and the output gap (1992Q 2 to 2006Q 3)

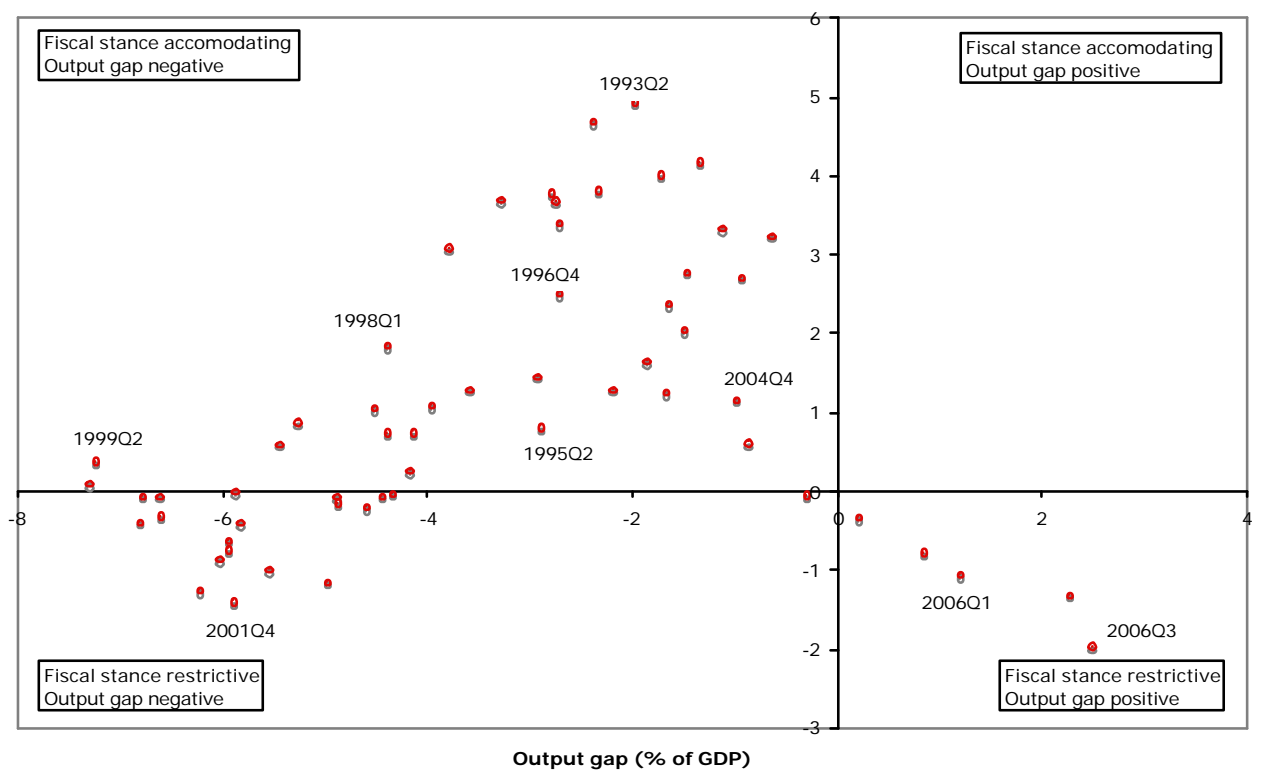

Source: Du Plessis and Boshoff (2007: figure 10) 
Figure 6 Impulse response of the government onsumption to aggregate supply and monetary policy shodks

Longer sample (1960+)

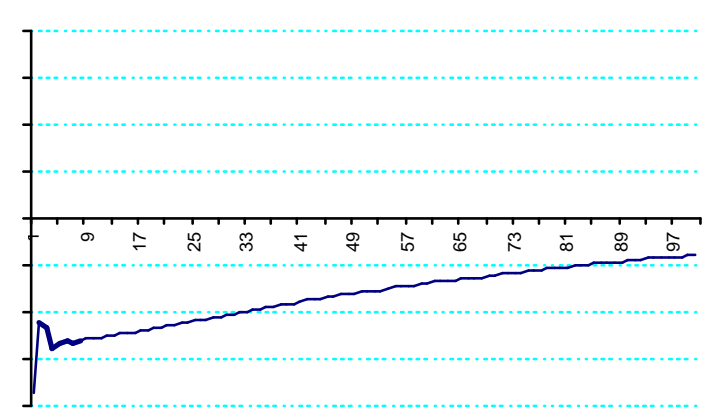

_ Response of Gov. Cons. as percentage of GDP to Supply Shock

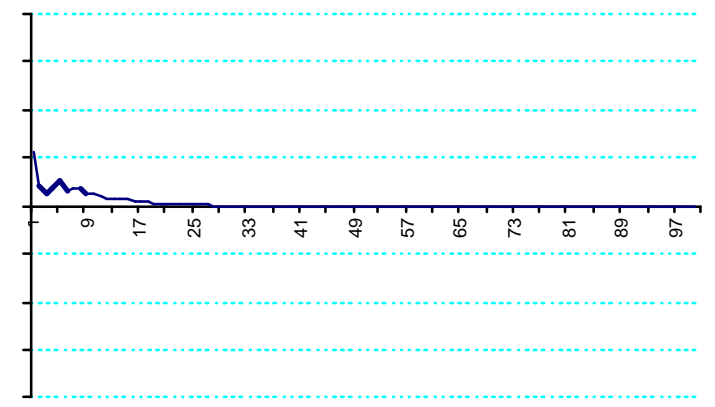

_ Response of Gov. Cons. as percentage of GDP to Monetary Shock
Shorter sample (1983+)
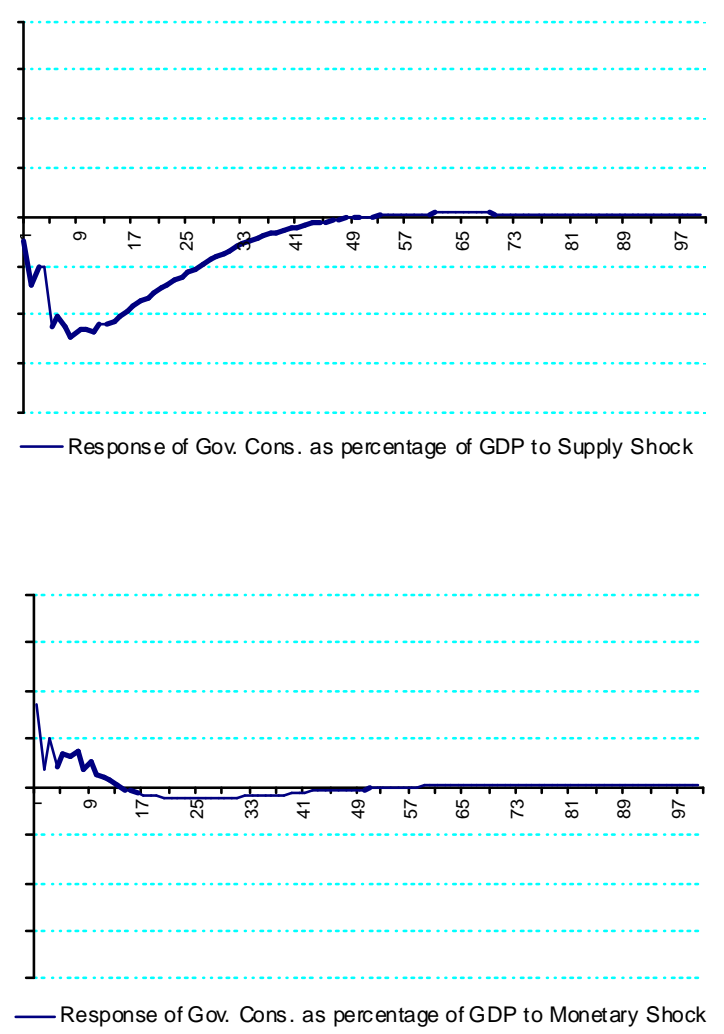
Figure 7 Impulse response of real G D P to a contractionary monetary policy shock

Longer sample (1960+)

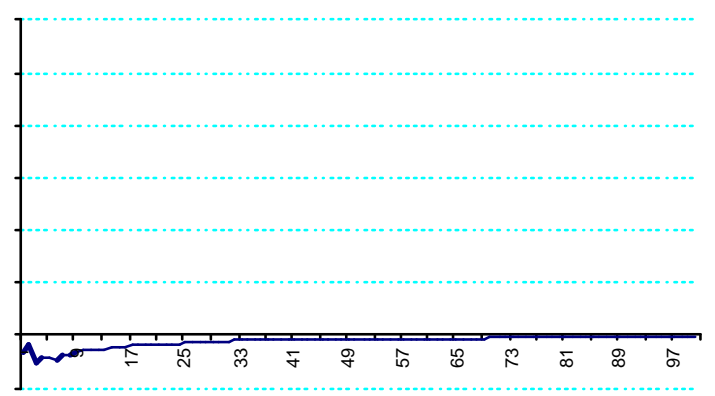

_ Accumulated Response of GDP to Monetary Shock
Shorter sample (1983+)

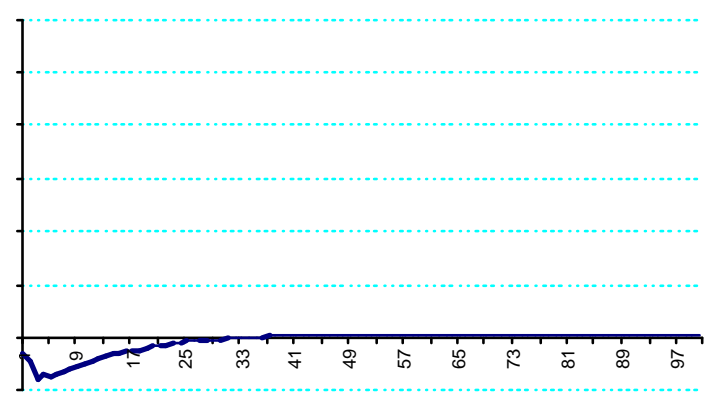

_ Accumulated Response of GDP to Monetary Shock 
Figure 8 Impulse response of the real interest rate to aggregate supply and fiscal policy shodks

Longer sample (1960+)

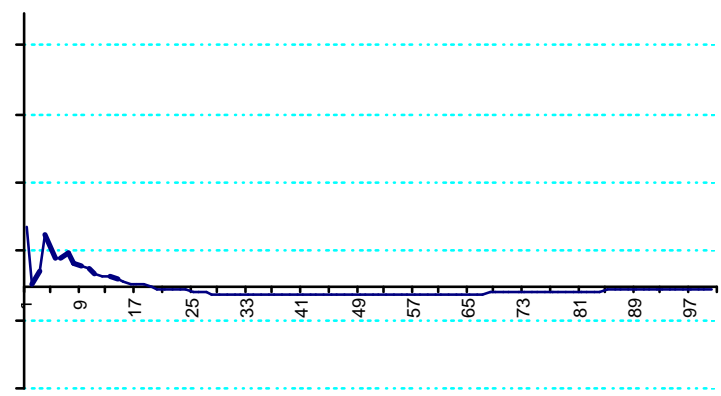

_ Response of Real hterest Rate to Supply Shock

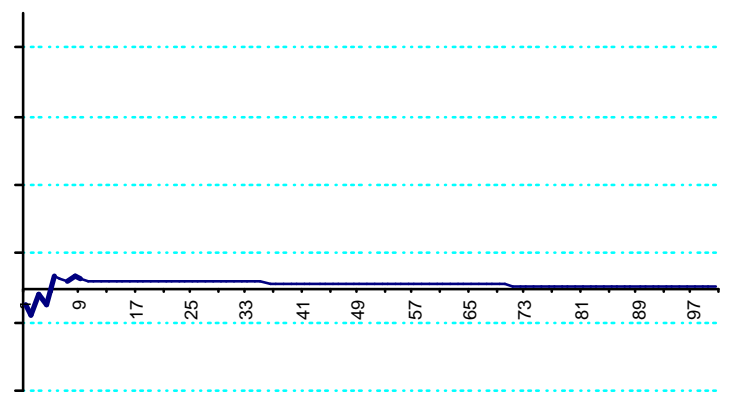

_- Response of Real Interest Rate to Fiscal Shock
Shorter sample (1983+)

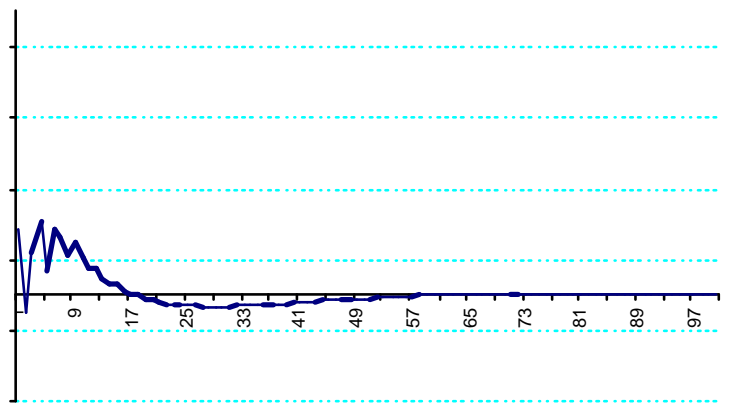

_Response of Real Interest Rate to Supply Shock

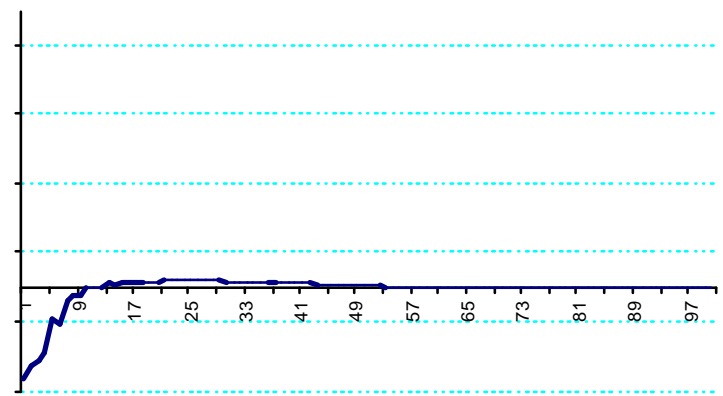

— Response of Real Interest Rate to Fiscal Shock 
Figure 9 A coumulated response of real G D P to fiscal policy shodks

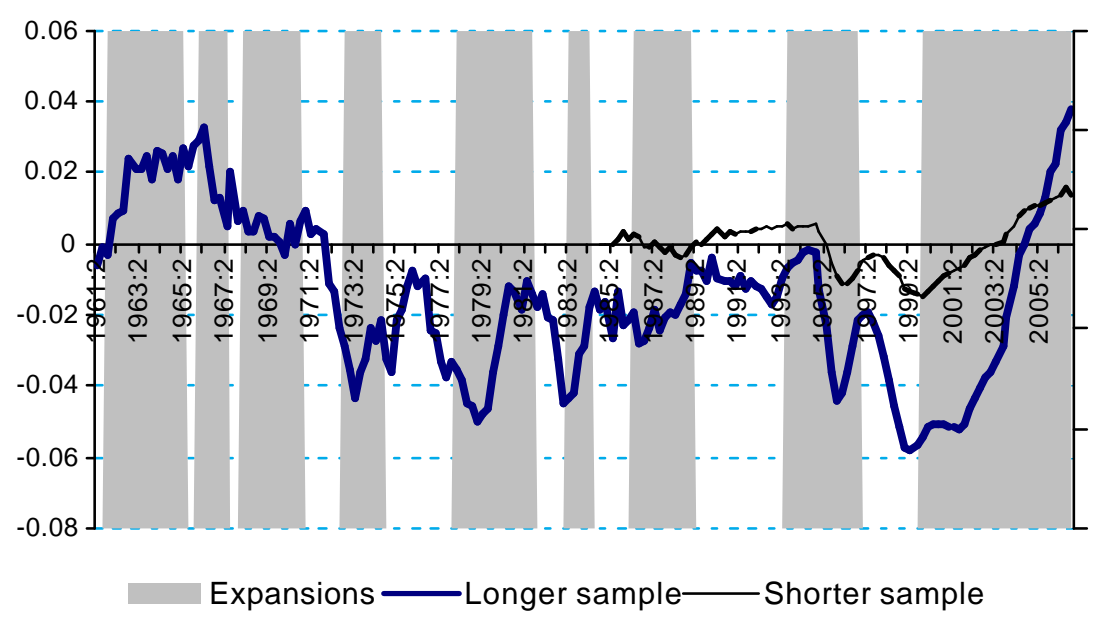

Figure 10 A coumulated response of real G D P to monetary policy shodks

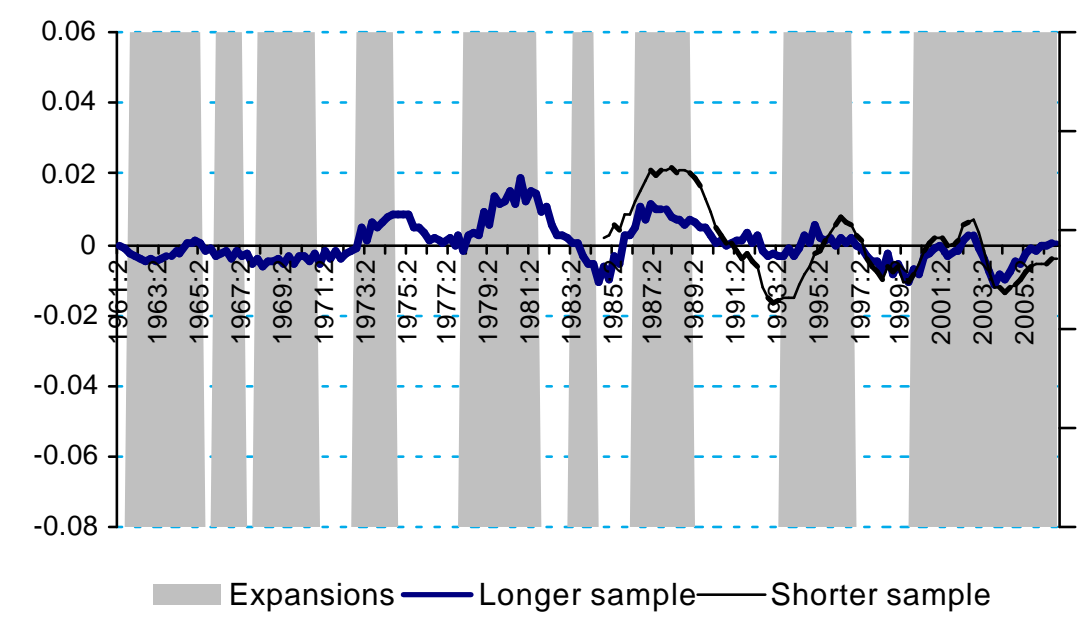




\section{REFERENCES}

Ajam, T. and J. Aron (2007). "Fiscal Renaissance in a Democratic South Africa." Lournal of African Economies, forthcoming: 1-31.

Aron, J. and J. Muellbauer (2005). "Monetary Policy, Macro-stability and Growth." World Economics, 6(4): 123-147.

--- (2006). Review of monetary policy in South Africa since 1994. Centre for Economic Policy Research. London, Working Paper Series no. 5831, September 2006.

Arora, V. and A. Bhundia (2003). Potential Output and Total Factor Productivity Growth in Post-Apartheid South Africa. Washington, IMF working paper: WP/03/178.

Blanchard, O. J. (1990). Suggestions for a New Set of Fiscal Indicators. Paris, OECD Department of Economics and Statistics Working Paper No. 79.

Blanchard, O. J. and D. Quah (1989). "The Dynamic Effects of Aggregate Demand and Supply Disturbances." American Economic Review, 79(4): 655-673.

Blanchard, O. J. and J. Simon (2001). "The Long and Large Decline in US Output Volatility." Brookings Papers on Economic Activity: 135-164.

Calitz, E. and F. K. Siebrits (2003). "Fiscal Policy in the 1990s." South African Journal of Economic History, 18: 50-75.

Calvo, G., A. Izquierdo and L. Mejía (2003). On the Empirics of Sudden Stops: The Relevance of Balance Sheets Effects. Boston, MA., NBER Working Paper, No. 10520.

Cavallo, E. and J. Frankel (2004). Does Openness to Trade Make Countries Less Vulnerable to Sudden Stops? Using Gravity to Establish Causality. Boston, MA., NBER Working Paper, No. 10957.

Cecchetti, S. G., A. Flores-Lagunes and S. Krause (2001). Has monetary policy become more efficient? A cross-country analysis. Ohio State University, Unpublished mimeograph.

Chand, S. K. (1977). "Summary Measures of Fiscal Influence." IMF Staff papers, 24(2): 405-449.

Clarida, R. and J. Galí (1994). "Sources of Real Exchange Rate Fluctuations: How Important are nominal Shocks?" Carnegie-Rochester Conference Series on Public Policy, 41: 1-56.

Du Plessis, S. A. (2004). Reconsidering the business cycle and stabilisation policies in 
South Africa. Cape Town, Paper presented at the 9th annual conference for econometric modelling in Africa.

--- (2006). "Reconsidering the business cycle and stabilisation policies in South Africa." Economic Modelling, 23(5): 761-774.

Du Plessis, S. A. and W. H. Boshoff (2007). The Potential for Counter-Cyclical Fiscal Policy in South Africa. Stellenbosch, University of Stellenbosch, Stellenbosch working paper 13/2007.

Du Plessis, S. A. and B. W. Smit (2003). Stabilisation policy in South Africa. Stellenbosch, Paper presented at the 8th annual conference for econometric modelling in Africa, held in Stellenbosch during July 2003.

--- (2007). "Countercyclical Monetary Policy in South Africa." Journal for Studies in Economics and Econometrics, 31(1): 79-98.

Du Plessis, S. A., B. W. Smit and F. Sturzenegger (2007). Measuring Potential Output and the Business Cycle in South Africa. Stellenbosch and Boston, University of Stellenbosch and Kennedy School of Government, Stellenbosch working paper $11 / 2007$.

Edwards, L. and R. Lawrence (2006). South African Trade Policy Matters: Trade Performance and Trade Policy. Cambridge, Ma., CID Working Paper No. 135, October 2006.

Fackler, J. S. and W. D. McMillan (1998). "Historical Decomposition of Aggregate Demand and Supply Shocks in a Small Macro Model." Southern Economic Journal, 64(3): 648-664.

Fatás, A. and I. Mihov (2003). "The case for restricting fiscal policy discretion." Quarterly Journal of Economics, 2003(November): 1419-1447.

Fedderke, J. W., R. H. J. de Kadt and J. M. Luiz (2001). "Indicators of political liberty, property rights, and political instability in South Africa." International Review of Law and Economics, 21: 103-124.

Fedderke, J. W. and P. Vaze (2001). "The Nature of South Africa's Trade Patterns by Economic Sector, and the Extent of Trade Liberalisation during the Course of the 1990s." South African Journal of Economics, 69(3): 436-473.

Frankel, J., B. W. Smit and F. Sturzenegger (2007). South Africa: Macroeconomic Challenges after a Decade of Success. Cambridge MA, CID Working Paper No. 133, April 2007.

Galí, J. (1992). "How Well Does the IS-LM Model Fit U.S. Data?" Quarterly Journal of Economics, 107(May): 709-738. 
Girouard, N. and C. André (2005). Measuring Cyclically-Adjusted Budget Balances for OECD Countries. Paris, OECD Economics Department Working Papers No. 434.

Guidotti, P., F. Sturzenegger and A. Villar (2004). "On the Consequences of Sudden Stops." Economia, 4(2): 171-214.

Horton, M. (2005). Role of fiscal policy in stabilization and poverty alleviation. In: M. Nowak and L. Ricci (eds.). Post-Apartheid South Africa. The first ten years. Washington, IMF.

Lucas, R. J. (2003). "Macroeconomic priorities." American Economic Review, 93(1): 1 14.

Manuel, T. A. (1998). The 1998 Medium Term Budget Policy Statement and Adjustments Estimate Cape Town, Presented to Parliament during October 1998.

--- (2001). Budget Speech. Cape Town, Presented to Parliament on 21 February 2001.

--- (2007). Budget Speech. Cape Town, Presented to Parliament on 21 February 2007.

Ortiz, A., F. Sturzenegger and E. Talvi (2007). Monetary and Fiscal Policies during a Sudden Stop: Is Tighter Brighter? Boston, MA, Kennedy School of Government, mimeograph.

Rogoff, K. (1985). "Can International Monetary Policy Cooperation be Counterproductive?" Journal of International Economics, 18(May): 199-217.

Romer, C. D. and D. H. Romer (1994). What ends recessions? Boston, Ma., NBER working paper, 4765.

Romer, D. H. (1993). "Openness and Inflation: Theory and Evidence." Quarterly Journal of Economics, 108(November): 869-903.

Schinasi, G. J. and M. S. Lutz (1991). Fiscal Impulses. Washington, IMF Working Paper, WP/91/91.

Shapiro, M. D. and M. W. Watson (1988). Sources of Business Cycles Fluctuations. In: S. Fischer (eds.). NBER Macroeconomics Annual, The MIT Press. 1988.

Stock, J. H. and M. W. Watson (2003). Has the business cycle changed? Evidence and explanations. Jackson Hole, Wyoming, Proceedings from the Federal Reserve Bank of Kansas City Symposium "Monetary Policy and uncertainty", August, 2003.

Swanepoel, J. A. (2004). "The Monetary and Fiscal Policy Mix in South Africa." South African Journal of Economics, 72(4): 730-758. 
--- (2007). Indicators of Fiscal Stance in South Africa: a Re-examination. Pretoria, South African Reserve Bank Discussion Paper, DP/07/03.

Swanepoel, J. A. and N. J. Schoeman (2003). "Countercyclical Fiscal Policy in South Africa: Role and Impact of Automatic Fiscal Stabilisers." South African Journal of Economic and Management Sciences, 6(4): 802-822.

Weeks, J. (1999). "Stuck in low GEAR? Macroeconomic policy in South Africa,199698." Cambridge Journal of Economics, 23: 795-811. 